\title{
Carotenoids From Red Fruit (Pandanus Conoideus Lam.) Extract Are Bioavailable : A Study In Rats
}

\author{
Mathelda Kurniaty Roreng ${ }^{1}$, Nurheni Sri Palupi ${ }^{2}$, Endang Prangdimurti ${ }^{2}$ \\ ${ }^{I}$ Departement of Agricultural Technology, Faculty of Agricultural and Agricultural Technology, Papua State \\ University \\ Jalan Gunung Salju Manokwari 98314 Indonesia \\ ${ }^{2}$ Departement of Food Science and Technology, Faculty of Agricultural Technology and Engineering, Bogor \\ Agricultural University, Darmaga Bogor 16680, Indonesia
}

\begin{abstract}
Red Fruit (Pandanus conoideus Lam.) is a Papuan indigenous fruit. This fruit has the potential of becoming functional food because of its carotenoid compounds that acts as an antioxidant and provitamin $A$. The high content of carotenoid in red fruit promotes the fruit empirically to prevent and cure various diseases. However, it has not been known how much carotenoid from red fruit can be absorbed and utilized by the body. This study aims (1) to evaluate the carotenoid bioavailability of red fruit extract; and (2) to the determine retinol accumulation factor in rat liver. The study was conducted with the approaches of carotenoid depletion and repletion. After 14 weeks depletion period and 2 weeks repletion period, it was obtained that retinol accumulation factor in red fruit extract group was 49.02 and positive control group was 42.41 . This indicate that to generate $1 \mu \mathrm{g}$ retinol in rat liver required $49.02 \beta$-carotene from red fruit extract or $42.41 \mu \mathrm{g}$ of pure $\beta$ carotene.
\end{abstract}

KEYWORDS: Bioavailability; carotenoid; red fruit; retinol, vitamin A.

\section{INTRODUCTION}

Red fruit (Pandanus conoideus Lam.) is one of Papua's indigenous fruit. This fruit has the potential as a functional food because of its carotenoid compounds that are health beneficial. Carotenoids have several biological activities namely provitamin A activity, antioxidant activity, protection againts ultraviolet rays, regulation of immune function and regulation division and proliferation of cells. ${ }^{[1]}$ Carotenoids may prevent some degenerative and chronic diseases such as hypercholesterolemia and heart disease that is due to the carotenoid antioxidant activity that is able to inhibit free radicals. ${ }^{[2]} \beta$-carotene compound is the main carotenoid with provitamin A activity that serves to vision, tissue differentiation, reproduction, and immunity. ${ }^{[3]}$ The high $\beta$-carotene content pillared red fruit to be a potential functional food source of provitamin A. WHO data indicates that the level of vitamin A deficiency in Indonesian children aged under five is as high as about 136.000 inhabitants. In pregnant women, the level of vitamin A deficiency is quite high, estimated at 74.000 inhabitants. ${ }^{[4]}$ Results of vitamin A deficiency cause physiological disorders such as impaired growth, vision, and the immune system, which in turn will affect productivity.High content of active components in a food does not guarantee that all components can be absorbed and utilized by the body. Measurements of bioavailability of carotenoid provitamin A from red fruit extract is necessary to determine the amount of carotenoids that can be absorbed and converted to retinol in the body so that it can be utilized as retinol, vitamin A and antioxidants.

The purpose of this study were: (1) to evaluate bioavailability of red fruit extract on rat liver and plasma, (2) to determine the retinol accumulation factors $(\mathrm{RAF})$ of red fruit extract on rat liver.

\subsection{Materials and Equipments}

\section{MATERIALS AND METHODS}

The materials used consisted of Hityom red fruit (Manokwari, West Papua), male white rat (Sparague Dawley strain) age 21 days (BPOM Jakarta), rat diets (CCO corn oil, casein technical, cellulose technical, mineral mix, vitamin mix , cornstarch and water). Chemicals used include $\mathrm{KOH}$, hexane, ethanol, methanol, acetonitrile, $\beta$-carotene and all-trans retinol (Sigma).The equipment used was presser and oil extraction equipment, rat surgical equipment, glassware for chemical analysis, analytical scales O'house, vortex, centrifuge, spectrophotometer Shimadzu UV-VIS 160 and HPLC (High Performance Liquid Chromatography) Shimadzu C-R6A Chromatopac. 


\subsection{Stages of Research}

Stages of the research are: (1) extraction and analysis of chemical constituents of red fruit extracts, and (2) red fruit extract carotenoid bioavailability analysis in rat. The extraction was conducted by using stamping method. ${ }^{[5]}$ Furthermore, the content of total carotenoids and $\beta$-carotene of red fruit extracts was analyzed. ${ }^{[6]}$

Carotenoid bioavailability analysis was conducted by vitamin A repletion and depletion method in rat. Rat was adapted for 10 days and then was depleted of vitamin A to vitamin A deficiency. At this stage, two rats every 2 weeks was terminated to see the content of rats retinol depletion. Rats were divided into 4 groups $(n=6)$ and were repleted for 2 weeks. Rat diets given the treatment are presented in Table 1. Preparation of standard diets based on the Association of Official Analytical Chemistry. ${ }^{[7]}$

Table 1. Rat Diets During Maintenance

\begin{tabular}{|c|c|c|c|}
\hline $\begin{array}{l}\text { Groups } \\
(\mathrm{n}=6)\end{array}$ & $\begin{array}{l}\text { Adaptation periods } \\
\text { (10 days) }\end{array}$ & $\begin{array}{l}\text { Depletion periods } \\
\text { (14 weeks) }\end{array}$ & $\begin{array}{l}\text { Repletion periods } \\
(2 \text { weeks })\end{array}$ \\
\hline Standard & Standard diets & Standard diets & Standard diets \\
\hline Negative control & Standard diets & $\begin{array}{l}\text { Standard diets } \\
\text { without vit. A }\end{array}$ & Standard diets without vit. A \\
\hline Positive control & Standard diets & $\begin{array}{l}\text { Standard diets } \\
\text { without vit. A }\end{array}$ & $\begin{array}{l}\text { Standard diets without vit. A+ } \\
\beta \text {-karoten }\end{array}$ \\
\hline Red fruit extracts & Standard diets & $\begin{array}{l}\text { Standard diets } \\
\text { without vit. A }\end{array}$ & $\begin{array}{l}\text { Standard diets without vit. A } \\
\text { +red fruit extracts }\end{array}$ \\
\hline
\end{tabular}

The amount of sources of vitamin A was added to the daily diets based on the needs of $\beta$-carotene in rat that is equal to $180 \mathrm{mg} \beta$-carotene ${ }^{[8]}$ Rats wer fed between $4 \mathrm{PM}$ and $8 \mathrm{PM}$ with free access to water. Each rat was placed in a separate cage with room temperature $22{ }^{\circ} \mathrm{C}$. Rat was weighed every three days.Rat termination was done by cervical dislocation. Blood was taken from the heart by using a syringe, and then was inserted into the tube containing an anticoagulant. Blood was centrifuged at $600 \mathrm{~g}$ and the plasma obtained was stored at $-20{ }^{\circ} \mathrm{C}$ until retinol analysis. Liver was weighed and wrapped with alumunium foil and was stored at $20{ }^{\circ} \mathrm{C}$ until liver retinol analysis.Plasma retinol analysis was conducted according to Zakaria et.al. ${ }^{[9]}$ The liver retinol analysis was conducted according to Furusho et al. ${ }^{[10]}$ Retinol accumulation factor was obtained by calculating the ratio of total $\beta$-carotene diets consumed during the accumulation of liver retinol on repletion periods. Accumulation of liver retinol was calculated by subtracting total liver retinol after the repletion with total liver retinol after depletion of vitamin A.

\subsection{Statistical Analysis}

Statistical analysis of the data was determined for plasma retinol, liver retinol and retinol accumulation factor (RAF). The result were expressed as the mean value \pm standard error of the mean. Analysis variance (ANOVA) was used to determine differences beetwen diet treatments, with the SAS Program. Differences associated with $\mathrm{p}<0.05$ were regarded as significant.

\subsection{Red Fruit Extract and Rat Diets Chemical Content}

\section{RESULT AND DISCUSSION}

Red fruit extracts was obtained from the extraction method of pressing with a yield of $8 \%$. Chemical analysis of the data showed that the total carotenoids of red fruits extracts was $265.55 \mathrm{ppm}$ and the content of $\beta$ carotene was $102.71 \mathrm{ppm}$. This data is quite different from the $\beta$-carotene data in several previous studies that range from 123-4583 ppm ${ }^{[11],[12], 13]}$. The variation of $\beta$-carotene content in red fruit are generally caused by the differences in varieties, climate, space to grow and extraction methods. According to Rodriguez-Amaya, differences in $\beta$-carotene content is also caused by post-harvest handling, processing and storage of fruit. ${ }^{[14]} \beta$ carotene content of the data is then used as the basis for preparation of red fruit extract diets rat group.

The results on $\beta$-carotene content analysis of the positive control diets was $3.94 \mu \mathrm{g} / \mathrm{g}$, while the red fruit extract diets was $3.96 \mu \mathrm{g} / \mathrm{g}$. Composition per kg diets for each group are shown in Table 2. 
Tabel 2. Composition of Rat Diets per Kg

\begin{tabular}{lcccc}
\hline Materials & Standard group & $\begin{array}{c}\text { Negative control } \\
\text { group }\end{array}$ & $\begin{array}{c}\text { Positive control } \\
\text { group }\end{array}$ & Red Fruit Extracts group \\
\hline Casein $(\mathrm{g})$ & 115.85 & 115.85 & 115.85 & 115.85 \\
Corn oil (g) & 77.66 & 77.66 & 77.66 & - \\
Fiber (g) & 9.38 & 9.38 & 9.38 & 9.38 \\
Corn starch(g) & 699.95 & 699.95 & 699.95 & 699.95 \\
Water (g) & 38.55 & 38.55 & 38.55 & 38.55 \\
Mineral mix (g) & 48.58 & 48.58 & 48.58 & 48.58 \\
Vit. mix (g) & 10.00 & - & - & - \\
Vit. without Vit.A & - & 10.00 & 10.00 & 10.00 \\
(g) & - & - & 9.00 & - \\
$\beta$-karoten (mg) & - & - & - & 87.50 \\
Red fruid extracts & - & & & \\
(g) & & & & \\
$\mathrm{D}=$ Depletion, S= Standard, KN = Negative control, KP = Positive control, EBM = Red fruit extracts
\end{tabular}

\subsection{Rat Conditions During Maintenance}

The purpose of depletion period is to reduce the vitamin A in the liver. During the depletion period (14 weeks) there were visible health differences between standards rat and rat in depletion of vitamin A. Standards rat looked healthy and fresh while depletion rat showed a health decline, eye colors are pale and wound around the eyes. Physical changes reserves of vitamin A in the liver, causing disruption of metabolism and disruption of the immune system. According to the Animal Nutrition Committee, vitamin A deficiency greatly affect the health and growth of the rat including: (1) visual impairment due to lack of 11-cisretynaldehyde which is an important component of visual pigment, (2) bone disorder caused by deficient bone cell division causing retardation, and (3) reproductive failure in male and female rat. ${ }^{[15]}$ Rat diets consumption during depletion did not show a difference between standard group rat with the depletion group. The average consumption of the daily standard diets is $16.85 \mathrm{~g}$ while the depletion is $15.83 \mathrm{~g}$. During repletion, the average consumption of daily standard diets for the standard group, negative control group, positive control group and a group of red fruit extracts respectively were $259.57 \mathrm{~g}, 223.01 \mathrm{~g}, 233.17 \mathrm{~g}$ and $216.44 \mathrm{~g}$. Differences in this consumption affects the amount of $\beta$-carotene consumed namely the positive control group of $918.54 \mu \mathrm{g}$ and the red fruit extract group of $858.10 \mu \mathrm{g}$.Rat deficient in vitamin A that was repleted with pure $\beta$-carotene and red fruit extract showed an increase of better health while in the negative control group rat continued to show health and physical activity decline. Results of weight variance analysis of rats at the end of the repletion showed that there is a significant difference between the control group and negative control group, but the standard group was not significantly different from the positive control group or the red fruit extract group. This indicates that the extract of red fruit can meet the needs of vitamin A sufficient enough to support growth.

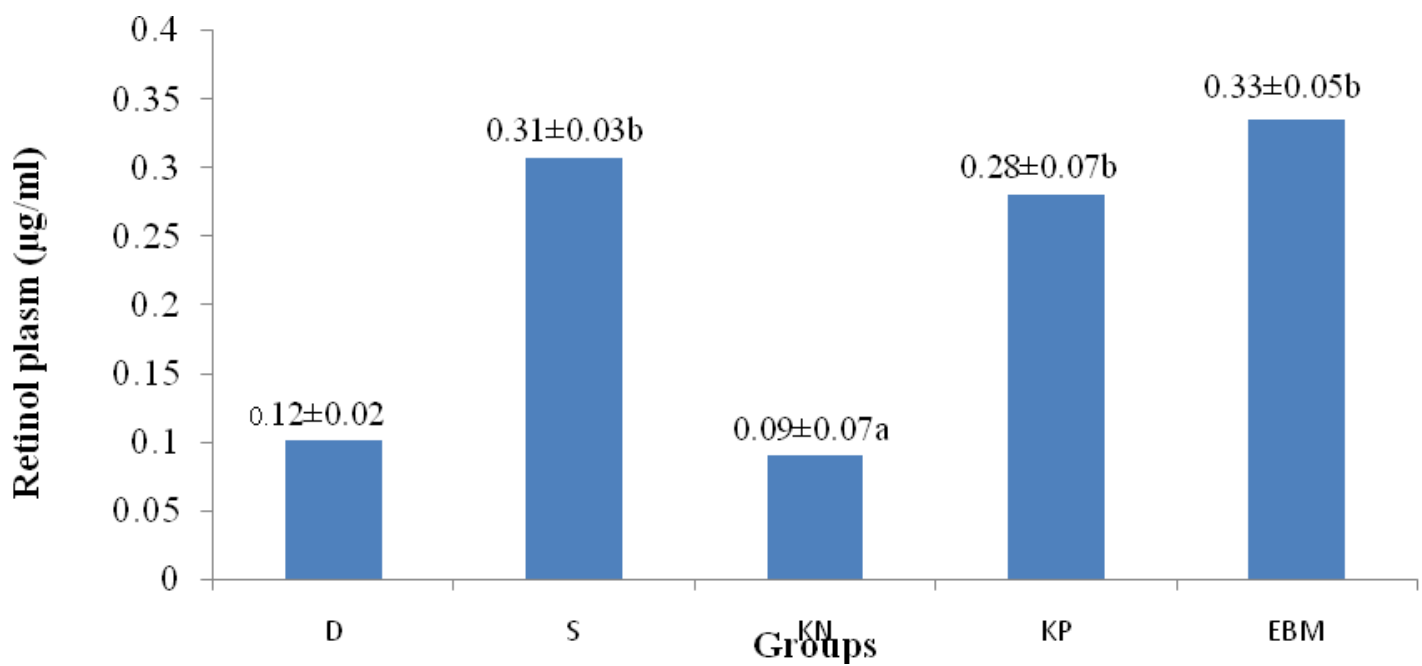

$\mathrm{D}=$ Depletion, $\mathrm{S}=$ Standard, $\mathrm{KN}=$ Negative control, $\mathrm{KP}=$ Positive control, $\mathrm{EBM}=$ Red fruit extracts

Fig 1. Histogram of Rat Plasma Retinol Content 


\subsection{Plasma Retinol Content}

Initial state plasma retinol content of rat before the depletion was $5.81 \mu \mathrm{g} / \mathrm{ml}$. After the depletion, plasma retinol content was $0.12 \mu \mathrm{g} / \mathrm{ml}$, a decline by $97.93 \%$. At the end of the repletion, the intervention group with red fruit extract showed the highest plasma retinol content of $0.33 \mu \mathrm{g} / \mathrm{ml}$. An increase of $178.42 \%$ of plasma retinol content at the end of depletion. Plasma retinol content of standard group, positive control and negative control group respectively are 0.31. 0.28 and $0.09 \mu \mathrm{g} / \mathrm{ml}$ (Fig 1).Results of analysis of variance showed that plasma retinol content was not significantly different among standards groups, positive control group and the red fruit extract group. Conversely, negative control group showed significant differences with the three groups. Plasma retinol content from the red fruit extract was higher than the standard group due to vitamin A status of rat that differs between the two groups in which the standards are not deficient in vitamin A. According to Parvin and Sivakumar, $\beta$-carotene conversion to retinol is higher if rat are in deficiency of vitamin A. ${ }^{[16]}$

\subsection{Liver Retinol Content}

Liver retinol content in early depletion was $3.75 \mu \mathrm{g} / \mathrm{g}$, and at the end of the depletion became 0.16 $\mu \mathrm{g} / \mathrm{g}$. After the repletion. standard group showed significant differences with the other treatment groups. This is due to the standard group did not undergo depletion resulting in the accumulation of retinol in the liver which is very high in the amount of $46.52 \mu \mathrm{g} / \mathrm{g}$. In contrast to the negative control group decreased liver retinol up to $96.16 \%$ with retinol content of $0.01 \mu \mathrm{g} / \mathrm{g}$.

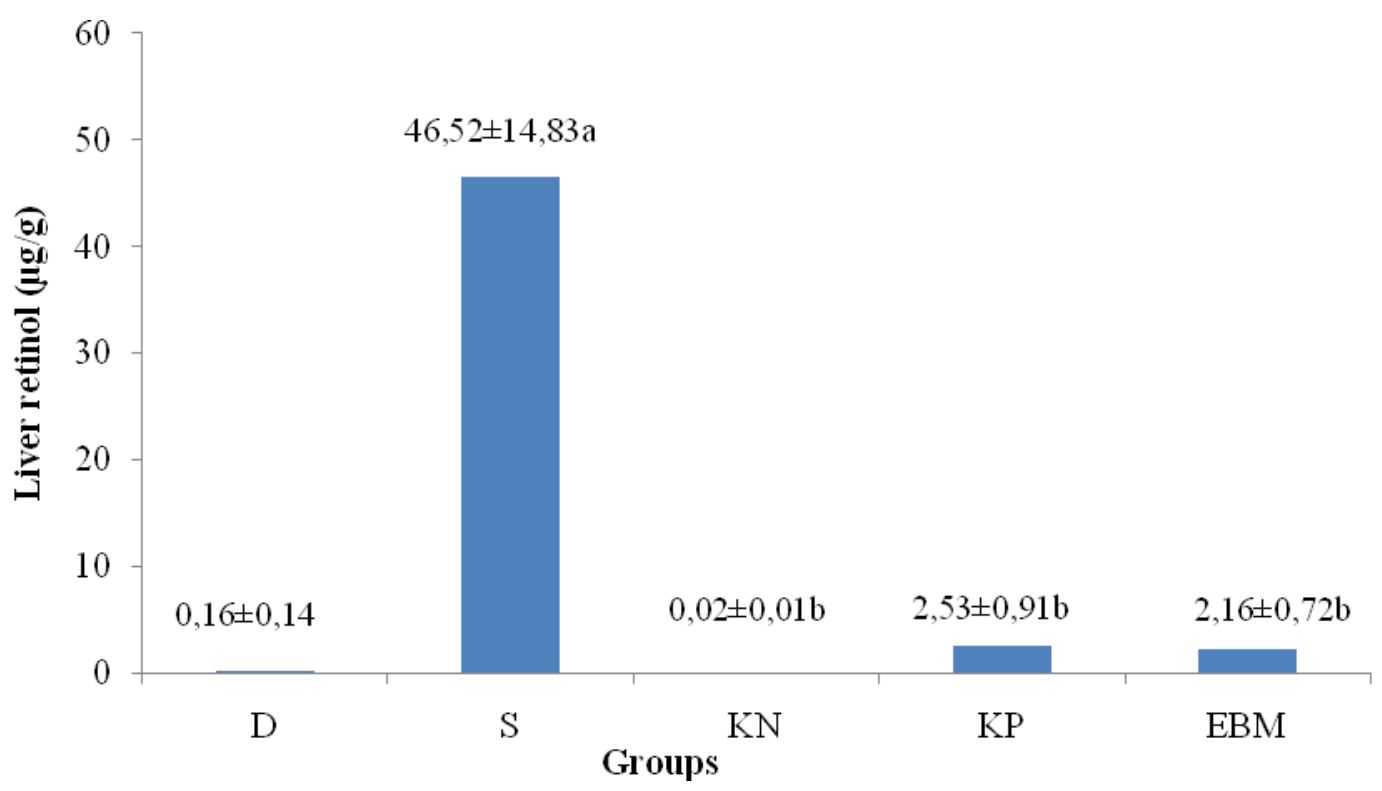

$\mathrm{D}=$ Depletion, $\mathrm{S}=$ standard, $\mathrm{KN}=$ Negative control, $\mathrm{KP}=$ Positive control, EBM $=$ Red Fruit Extracts

\section{Fig 2. Histogram of Rat Liver Retinol Content}

Increased content of retinol occured in the group of rat that was interfered with $\beta$-carotene and red fruit extracts. Liver retinol content of positive control group was $2.53 \mu \mathrm{g} / \mathrm{g}$ whereas in the extract of red fruit reaches $2.16 \mu \mathrm{g} / \mathrm{g}$. These results suggest that $\beta$-carotene in both the group of diets can be absorbed and stored in the liver. The increased of liver retinol in the red fruit extract group reaching 13.5 times of the content of retinol depletion period indicate that extracts of red fruit is a potential source of vitamin A.

\subsection{Carotenoid Bioavailability of Red Fruit Extract}

Bioavailability is expressed with the value of retinol accumulation factors (RAF). which is calculated based on the amount of retinol (vitamin A) formed in the liver after rat was deficient of vitamin A and repleted with intervention diets containing provitamin $\mathrm{A} .{ }^{[9]} \mathrm{RAF}$ value of pure $\beta$-carotene diets and red fruit extract diets can be seen in Table 3 . 
Table 3. Retinol Accumulation Factor Value Positive Control Group and Red Fruit Extract

\begin{tabular}{lccc}
\hline Groups & $\begin{array}{c}\text { Consumption of } \\
\beta \text {-carotene }(\mu \mathrm{g})\end{array}$ & $\begin{array}{c}\text { Accumulation of } \\
\text { liver retinol }(\mu \mathrm{g}) \\
(\mathrm{b})\end{array}$ & $\begin{array}{c}\text { Retinol Accumulation } \\
\text { Factor } \\
(\mathrm{a} / \mathrm{b})\end{array}$ \\
\hline Positive & $918.54 \pm 127.55$ & $27.64 \pm 13.84$ & $42.41 \pm$ \\
Control & & & 27.47 \\
Red Fruit & $858.10 \pm 118.11$ & $19.68 \pm 6.04$ & $49.02 \pm$ \\
Extract & & & 21.76 \\
\hline
\end{tabular}

RAF value of the positive control group (pure $\beta$-carotene diets) was 42.41 , not significantly different from RAF value of red fruit extract which reached 49.02. This value indicates that to produce $1 \mu \mathrm{g}$ of retinol in liver, requires $42.41 \mu \mathrm{g}$ pure $\beta$-carotene or $49.02 \mu \mathrm{g} \beta$-carotene from red fruit extracts. The relative bioavailability of pure $\beta$-carotene towards red fruit extract is $86.52 \%$. It shows that extracts of red fruit is a potential source of vitamin A.Carotenoid bioavailability is influenced by various internal and external factors such as the composition of food carotenoids, fatty food and fiber, food matrix, food preparation before consumption, particle size, the interaction of carotenoids for absorption, metabolism and transport processes. [17],[18] Some carotenoids bioavailability studies have been conducted by generating RAF value and bioavailability (RAF relative) that varies depending on the type of intervened food in diets (Table 4.)

Table 4. Retinol Accumulation Factor Value of Some Types of Food Fresh ${ }^{[19],[20],[21]}$

\begin{tabular}{lccc}
\hline Food Sample & RAF & RAF Control group & Relative Bioavailability \\
\hline Cassava leaves & 27.5 & 13.5 & 49.09 \\
Bocaiuva & 3.5 & 7.3 & 208.57 \\
Spinach & 95.3 & 15.4 & 16.16 \\
Amarantus & 43.1 & 15.4 & 35.73 \\
Viridis & & & 8.61 \\
Xanthosoma & 178.9 & 15.4 & \\
sagittifolium & & & \\
\hline
\end{tabular}

\section{CONCLUSION}

Red fruit extracts carotenoids can be absorbed, metabolized and stored in the liver of rat. Retinol Accumulation Factor of red fruit extract retinol is 49.02 and the relative bioavailability of the red fruit extract carotenoid against pure $\beta$-carotene is $86.52 \%$.

\section{REFERENCES}

[1] J.A.Olson, Biological actions of carotenoids, J Nutr ,119, 1989, 94-95.

[2] D. Dutta, R. Utpal Chaudhuri, C.Runu, Structure, Health Benefits, Antioxidant property and processing and storage of carotenoids [review], Afr J Biot, 4, 2005, 1510-1520.

[3] G.F.M. Ball, Fat soluble vitamins assay in food analysis (New York: Elselvier Science Publish.Co.Inc, 2000).

[4] World Health Organization. Global prevalence of vitamin A deficiency in populations at risk 1995-2005. WHO global database on vitamin A deficiency (Geneva : WHO, 2009).

[5] N. Andarwulan, N.S. Palupi, Susanti, Proc. PATPI National Seminar, Yogyakarta, 2006. 504-511.

[6] Packer, Extraction of carotenoid for palm oil (New York: Cornell University,1992).

[7] Association of Official Analytical Chemistry. 5th ed (Arlington: V.A.AOAC Inc, 2005).

[8] Moore in F.R. Zakaria, M. Djaelani, Setiana, E. Rumondong, Nurrocmah, Carotenoid bioavailability of vegetables and carbohydrate-containing foods measured by retinol accumulation in rat livers, J Fod Comp. Anal, 13, 2000, $297-310$.

[9] F.R. Zakaria, M. Djaelani, Setiana, E. Rumondong, Nurrocmah, Carotenoid bioavailability of vegetables and carbohydratecontaining foods measured by retinol accumulation in rat livers, J Fod Comp. Anal, 13, 2000, 297-310.

[10] T. Furosho, E. Kataoka, T. Yasuhara, M. Wada, S. Masushige, Retinol equivalence of carotenoids can be evaluated by hepatic vitamin A content, Int. J Vitam Nutr Res, 70, 2000, 43-47.

[11] I.M. Budi, Kajian kandungan zat gizi dan fisikokimia berbagai jenis minyak buah merah (Pandanus conoideus L.) hasil ekstraksi secara tradisional di kabupaten Jayawijaya Propinsi Irian Jaya, master theses, Program Pascasarjana Institut Pertanian Bogor, Indonesia, 2001.

[12] Murtiningrum, Ekstraksi minyak dengan metode wet rendering dari buah pandan (Pandanus conoideus L.) dan pemurnian dengan filtrasi membran, master theses, Program Pascasarjana Institut Pertanian Bogor, Indonesia, 2004.

[13] Susanti, Karakterisasi ekstrak buah merah (Pandanus conoideus Lam.) dan uji biologis terhadap proliferasi sel limfosit mencit, dipl skripsi, Institut Pertanian Bogor, Indonesia, 2006.

[14] D.B. Rodriguez-Amaya, A Guide to carotenoid analysis in foods (Washington DC: ILSI Human Nutrition Institute, 2001).

[15] Committee on Animal Nutrition National Research Council. Nutrient requirements of laboratory animals (Washington DC: National Academy Press, 1995).

[16] S.G. Parvin. B. Sivakumar, Nutritional status affect intestinal caroten cleavage activity and caroten conversion to vitamin A in rats, J Nutr, 130, 2000, 573-577. 
[17] J.A. Olson, Bioavailability of carotenoids, Arch. Latinoam. Nutr, 49, 1999, 26-33.

[18] K.H.V.H. Hof, C.E. West, J.A. Weststrate, J.G.A.J, Dietary factors that effect the bioavailability of carotenoids, J Nutr, 130, 2000, 503-506.

[19] E.G.A. Siqueira, S.F. Arruda, R.M. de Vargas, E.M.T. de Souza, $\beta$-Carotene from cassava (Manihot esculenta Crantz) leaves improves vitamin A status in rats, Comparative Biochemistry and Physiology. Part C , 146, 2006, 235-240.

[20] M.I.L. Ramos, E.M.A. Siqueira, C.C. Isomura, A.M.J. Barbosa. S.F. Arruda, Bocaiuva (Acromia aculeata (Jacq.) Lodd) improved vitamin A status in rats, J. Agric Food Chem, 55, 2007, 3186-3190.

[21] I.T. Graebner, E.M.A. Siqueira, S.F. Arruda, M.T.S. Elizabeth, Carotenoids from native Brazilian dark-green vegetables are bioavailable: A Study in rats, Nutrition Research, 24, 2004, 671-679. 